\title{
Socio-Physical Transformation towards Sustainable Urban Morphology through Land Readjustment in Indonesia
}

\author{
Ngakan Made Anom Wiryasa, Ngakan Ketut Acwin Dwijendra* \\ Faculty of Engineering, Udayana University, Denpasar, Bali, Indonesia
}

Received February 19, 2021; Revised April 19, 2021; Accepted May 11, 2021

\section{Cite This Paper in the following Citation Styles}

(a): [1] Ngakan Made Anom Wiryasa, Ngakan Ketut Acwin Dwijendra , "Socio-Physical Transformation towards Sustainable Urban Morphology through Land Readjustment in Indonesia," Civil Engineering and Architecture, Vol. 9 , No. 3, pp. 874 - 882, 2021. DOI: 10.13189/cea.2021.090329.

(b): Ngakan Made Anom Wiryasa, Ngakan Ketut Acwin Dwijendra (2021). Socio-Physical Transformation towards Sustainable Urban Morphology through Land Readjustment in Indonesia. Civil Engineering and Architecture, 9(3), 874 - 882. DOI: 10.13189/cea.2021.090329.

Copyright $\odot 2021$ by authors, all rights reserved. Authors agree that this article remains permanently open access under the terms of the Creative Commons Attribution License 4.0 International License

\begin{abstract}
In the development sector, the need for land is increasing, resulting in the higher land value and land use mismatches. Urban areas have a relatively fixed area, while the need for land continues to increase. Weaknesses in urban management lead to speculation, illegal land use, and slums. Development activities should impact the physical, environmental, economic, and social conditions of the community [29]. The development process often pays little attention to these matters. In the last few decades, we have observed a very rapid social transformation process in urban areas that has changed the morphology of Indonesian cities. This transformation has accelerated after the implementation of regional autonomy in Indonesia since 1999. Land conflicts in urban areas do not end, so it is necessary to consolidate land as an activity to restructure land tenure, land use, and land acquisition to improve environmental quality and preserve natural resources and ecosystems by involving the community to play an active role. This study aims to evaluate the extent to which land readjustment in Indonesia can improve the efficiency and productivity of morphological transformation of urban land use, the extent of community participation, and its alignments to low-income people and their handling of slum areas. This study uses qualitative exploratory research methods and normative juridical approach methods through library studies. It uses the legislative approach, fact approach, and conceptual approach and primary data in the form of interviews to complete library studies. The study
\end{abstract}

results show that land readjustment can improve the efficiency and productivity of morphological transformation of urban land use optimally and it is an effective way that contributes to the spatial planning that is more just, integrated and sustainable.

Keywords Socio-Physical Transformation, Sustainable Urban Morphology, Land Readjustment

\section{Introduction}

Cities will always grow and develop in line with the development of the socio-cultural, economic and political life. City development is the result of the work of human thought constructs both at the level of adaptation to the environment and adjustment. Culture is one of the factors that cause the images of the city to change [13]. City people with certain backgrounds from traditional to modern life patterns influence changes in the formation of cities. The factor of the stability of the community's culture in maintaining the penetration of outside culture (the influence of acculturation and assimilation of culture) and the intensity of the influence of change are two factors that greatly determine the process of urban development [15][30]. In addition, natural factors such as geographical conditions, land structure and so on play a very important role in the growth and development of cities [47]. [48] 
revealed that there are three factors that play an important role in the process of urban growth, namely ecology, technology and social organization. The development of the city is a continuous process that is closely related to changes in the socio-cultural community. The existence of the city cannot be separated from the early history of development, current conditions, and the face of the city in the future.

Meeting the need for land is one step to achieving social welfare for all Indonesian people who are part of the government's responsibility. But the more human life develops, the more complex the land problem is, especially in urban areas. Urban areas have a relatively fixed area, while the need for land is increasing. The many interests of various parties in the use of space in urban areas also add to the complexity of spatial planning. Weaknesses in urban management will indirectly lead to speculation, scarcity of urban land development for settlements, growth and development of land tenure and ownership, illegal or illegal use of land, slums area, etc. [2][29].

The development of cities is closely related to the function of time, this reminds us of the past, namely the historical aspect has played a very important role in shaping the morphology of the city (Mumford, 1967). The form of a city is not only a product, but also a process of accumulation of physical manifestations of non-physical life, which is influenced by the value system and norms prevailing at the time of its formation [45]. It can also be said to be an urban artifact, a city in the course of its history has and will form a morphological pattern as an implementation of the form of socio-cultural change in the society that forms it. Furthermore, when talking about the two things described above, namely the development and shape of the city, therefore, the development and shape of the city is an inseparable unity in seeing an urban condition, in this case in terms of the urban morphological pattern [25][30].

Bearing this in mind, in dealing with various land conflicts that never end, especially in urban areas, it is necessary to regulate land tenure and use optimally as well as efforts to improve the efficiency and productivity of urban land use through land consolidation/readjustment so that it can be used as an alternative solution for the government to realize the social function of the land as well as the quality of an urban environment that is orderly and neatly arranged [7][12].

\section{Literature Review}

Morphology is the formation of a city-shaped object on a wider scale. Urban morphology is the arrangement or formation of the state of the city as objects and systems that can be investigated structurally, functionally, and visually [43] [50]. The three elements of urban morphology are land use elements, road patterns and building types. From here the term "Townscape" [50] first appeared. From these definitions, city morphology can simply be interpreted as the physical forms of the city which are known structurally, functionally and visually. The morphology of a city can be different from one another so that the morphology of this city forms the characteristics or characteristics of a city.

Morphology is usually used to scale cities and regions. City morphology in the spatial existence of the characteristic of the city, namely the analysis of the shape of the city and the factors that influence it (Yunus, 2000). Therefore, the morphology of the city forms is not only limited to analyzing the shape of the city but also identifying the factors that influence the shape of the city. [43] stated that in the aspects of urban morphology, the determination of urban characteristics from various types of forms is fundamental, especially in relation to differentiating and mapping areas whose policies are also different in each region. With this theory, a research on urban morphology requires a study of city morphology with various types of forms or aspects. According to [43], city morphology has three components, namely the Ground Plan (road patterns, building blocks), building forms (building types) and land/building utilities. City form analysis includes: (1) Compact forms, consisting of squares (the square cities), rectangular cities, fan shaped cities, rounded cities, ribbon shaped cities, octopus or star shape (octopus/star shaped cities), unpatterned cities; and (2) Non-compact forms, consisting of fragmented cities, chained cities, split cities, and stellar cities.

The factors that influence the shape of the city are landscape or geographic, transportation, social, economic and regulatory factors. Besides being seen from the shape of the city and the factors that influence it, the morphology of the city can also be seen based on the type of urban morphology (Urban Morphology Type). The type of city morphology can be broken down by primary land use [43] [51]. This type of urban morphology is often known as land use. The theory of the type of city morphology is often known as the function of the building, structural, functional and visual study of urban morphology and urban design.

In structural city morphology study, structural analysis states that there is a separation of levels associated with tastes, preferences and lifestyles, as expressed by Alonso who uses the concentric zone division of Burgess to explain spatial distribution-residential mobility [52].

Study of urban morphology in functional, in 1748 Giambattista Nolli [47] an Italian architect, found a way to analyze an urban texture in terms of mass and space functions and how it relates functionally. The way to do this is by showing analytically all the masses and urban spaces that are public (and semipublic) into a specific figure/ground image. This method of analysis is called Nollidlan, where all masses that are public or semipublic are no longer expressed as a mass (in black), but are classified together with the spatial texture (in white) [49] [52]. 
Visual urban morphological study is a visual study of urban morphology can be seen in the linkage analysis which discusses the relationship of a place to another from various aspects as an urban generator [44]. In linkage analysis, three approaches are proposed, including visual linkage. In a visual linkage, two or more fragments (parts or shards of something) of the city are connected to become one visually. Five elements of visual linkage that create a visual relationship, namely lines, corridors, sides, axes and rhythm [42][49].

\section{Research Method}

This study uses a qualitative descriptive analysis with the intention of analyzing based on the characteristics of indoor activities that affect the physical factors of a city as a place to carry out activities and the physical forms of the environment which are caused by non-physical factors from the formation of a city morphology. The following methods are used: qualitative analysis research methods, normative juridical approach methods through library studies, the legislative approach, fact approach, and conceptual approach and primary data in the form of interviews to supplement library research. Land consolidation/readjustment is expected to increase the efficiency and productivity of the morphological transformation of urban land use optimally.

\section{Results and Discussion}

\subsection{How do we understand City Morphology?}

In the last few decades, we have observed a very rapid social transformation process in urban areas that has changed the morphology of Indonesian cities. This transformation has been accelerated after the implementation of regional autonomy since 1999. Our understanding of "city morphology" cannot be separated from the physical form of the city, which is formed primarily by physical-environmental conditions or the community's dynamic social-economic interactions. As a branch of geography and architecture, morphology studies the development of physical forms in urban areas, which are related to building architecture and the circulation system, open space, and urban infrastructure (specifical roads as the main spatial structure) [9][32][35]. Broadly speaking, the city's physical appearance is a visual and partial manifestation resulting from the interaction of the important components that form one another, which influences one another [1][14].

In its realization, the morphology of the city can be seen as an evolution of the history of the past city, and the design of the city for the present and urban planning for the future. On the one hand, in the present context of morphology, it is physically visible; but on the other hand, there is stored historical meaning that is more abstract, which is the reason for its existence.

Besides, morphology is the result of the urban planning and design process through a formal system in force (Regional Spatial Planning, Spatial Detail Plan, Building and Environmental Planning). However, city morphology is also formed from processes that work beyond the reach or control of the existing formal system, as we have encountered in many Indonesian cities. Overall, cities and their morphology mirror their communities' civilization [2][10][28].

Considering that land consolidation/readjustment can be a land acquisition method for development that prioritizes the principles of participation and justice, land consolidation/readjustment can also be used as an instrument for realizing participatory spatial planning and realizing regional development that is integrated with surrounding areas.

\subsection{Development of Urban Space in Indonesia: Urbanization and Its Impact}

It cannot be denied that the physical development of urban space is strongly influenced by urbanization [11][34]. The development of urbanization in Indonesia can be observed from 3 (three) aspects: first, the number of people living in urban areas (now reaching 120 million from a total of 230 million people); second, uneven population distribution (almost 70\% in Java with 125 million people and in Sumatra with 45 million people) [38][40]; and third, the high rate of urbanization, in which metropolitan cities, such as Jakarta (including Bekasi, Bogor and Tangerang), Surabaya, Bandung, Medan, Palembang and Makassar, are the main magnets. Statistical Bureau of Bali (2020) records show that since 1970, Indonesia's urban population fraction increased from $17.4 \%$ (1970) to $22.3 \%$ (1980), 30.9\% (1990), 43.99\% (2002) and, finally, $52.03 \%$ (2010). This means that within 40 years, urbanization has doubled the urban population three times larger [26][40].

In the future, urbanization is believed to continue to occur in Indonesia, both due to natural urban population growth, rural-urban migration and regional expansion [22][31]. With a moderate growth rate of $1.5 \%$ per year, the proportion of the city's population is expected to increase to $56.05 \%$ in 2015 to $60.39 \%$ in 2020 [40].

However, this process of rapid social transformation is not easy to manage. On the one hand, cities are the main catalyst of economic growth (the engine of growth). Cities are an ideal incubation for the birth of various innovations: locus where rich ideas compete with each other, without limitation, to achieve the highest efficiency in urban life [3][4]. Urbanization is seen as a rational choice for the community to improve their standard of living, making their lives more worthy and prosperous [5][41]. But on the 
other hand, as cities become modern, simultaneously the quality of urban life decreases significantly. Acute congestion, recurring floods and even more severe, inadequate drinking water supply, water and air pollution, and the spread of slums in urban areas, are all blurred portraits of cities, especially metropolitan cities in Indonesia [37]. These two opposing sides of urban development are referred to by experts as "the urban paradox".

With this critical condition, the urban poor will be the first victims. Without access to basic urban services, the poor live in dense dwellings (slums and squatters) in narrow urban spaces that are completely unfit for habitation. The poor become social groups that are very vulnerable to various urban disasters, including floods, fires and the spread of disease outbreaks [8][19]. In the long run, if we include climate change parameters, the vulnerability of the urban poor will be even higher. The contrasting physical appearance and architecture of the city (between luxury and slums) solidify how socio-economic inequality and segregation occur in urban areas [6][18].

\subsection{Socio-Physical Transformation in Urban Area}

Urbanization drastically changes the city's morphology, both in terms of the structure, function and face of the city. Socio-culturally, the phenomenon of "city" indicates the formation of the new and different network society in demand for infrastructure services [33][36]. The following three examples, Jakarta, Bandung and Gorontalo, can illustrate how quickly changes have occurred in Indonesian cities [24][41].

From the three examples above, we can observe that social transformation has changed the city's morphology. Several factors appear to be quite dominant in the process: (1) investment flows that encourage increased city productivity, especially those driven by private investment; (2) the existence of socio-economic infrastructures, such as roads and ports, and (3) increasing the status of autonomous cities (provincial capitals) [23][27]. These three factors are the main causes of urbanization, accelerating the transfer of urban space functions. The difference lies in the starting point of change (Jakarta since the 1960s, Bandung since the 1980s, and Gorontalo since the 2000s), and the role of the private sector largely determines the speed of transformation that occurs [16][20].

Nevertheless, modernization of the city does not necessarily erase the slums due to urban poverty that have not been completely overcome. During the last four decades (1980 - 2020), the number of poor people in urban areas actually showed a graph that increased from 9.5 million to 11.91 million. This contrasts with the number of poor people in rural areas which shows a downward trend from 32.8 million (1980) to 20.62 million (2020). Overall, the number of poor people is still very high. No less than 47,000 pockets of poverty are now scattered in various cities in Indonesia [17][21].

\section{Informalization}

Spatially, social transformation can be seen at least from the following 4 (four) phenomena that cannot be separated from urban development in Indonesia. Contemporary cities in Indonesia cannot be separated from the phenomenon of informalization, characterized by the number of street vendors who adorn the city's main corridors and socio-economic centres of the city (around shopping centres, entertainment centres and large mosques) [3][36].

When referring to taxpayer data that is still relatively small (ranging from 20 to $30 \%$ ), the existence of the informal sector in Indonesia has a substantial percentage (between $70 \%$ to $80 \%$ ) [37][39]. It is not surprising that metropolitan cities like Jakarta, Bandung, Surabaya, Medan and Makassar are filled with street vendors.

The existence of street vendors cannot be ignored from a local socio-economic point of view. It absorbs a large workforce while simultaneously reducing the number of unemployed massively in many large cities and metropolitan areas. With the unemployment rate in Jakarta in 2019, reaching 552 thousand people, street vendors provide alternative solutions for $27 \%$ of the population without jobs, which are not accommodated in the formal sector. The unemployment rate increased to 570,560 people in 2019. However, from a morphological perspective, the presence of street vendors often disrupts the functioning of the city (e.g., traffic jams), as well as providing a negative image for cities that look chaotic and reduce its visual value [35][38].

\section{Propagation and Compaction of Borders}

The American pattern more or less influences the development of cities in Indonesia: (1) large-sized houses (landed housing) which are often located in the suburbs (sub-urban/periphery), given the high price of the property (land and buildings) in the middle of the city; (2) the use of private vehicles (cars) offering "freedom of movement" in supporting the need for urban circulation, and (3) the availability of adequate transportation access (especially toll roads, where geographical distances are cut by time) [3] [9].

From a morphological perspective, this pattern has triggered the spread of urban development horizontally in all directions (urban sprawling), encouraging the movement of people and goods that are not only wasteful of energy, but also polluting the environment (large amounts of energy consumption, and large carbon releases also to the atmosphere). The propagation, which is then followed by compaction (densification), occurs far from the centre of activity to the periphery, exceeding the city's administrative boundaries. The city centre is no longer single (mono-nucleus) but is spread over several strategic locations (multi-nucleus). Villages in the suburbs are quickly turning into new urban activity centres, often without careful planning and design. Agricultural lands and 
smallholder plantations are converted into densely developed lands to respond to economic interests over increasingly scarce urban spaces, but often neglect the environment's carrying capacity [4][6].

\section{Elimination of Green Open Space}

The morphological characteristics of Indonesian cities also show a significant decrease in the area of green open space. Big cities like Jakarta, Surabaya and Bandung have lost a lot of green open space so that the area is now only around $10 \%$ of the administrative area. Meanwhile, some cities can still maintain their forest area above $30 \%$, such as Balikpapan and Ternate, although today is also facing serious urbanization pressures due to urban land scarcity. In Ternate, for example, this pressure resulted in the use of urban forest, which was quite far from the coastline, in the hills of Mount Gamalama, which was still active. This physical development is hazardous from the point of view of disaster mitigation because it increases the risk of disasters that originate from volcanic activities of Mount Gamalama [17][24].

Indeed, green open space plays an essential role as the city's lungs (carbon concentration dissipation) and a place for social interaction and economic assets of the city, such as for tourism activities. For many writers, urban parks are often likened to "the urban paradise". The existence of green open space is essential in terms of developing democracy in the country that is now undergoing a maturation process. For Frederic Law Olmsted, the landscape architect who realized Central Park in New York in the 1850s, a green city is a prerequisite for developing a healthy democratic climate. "If you want a healthy democracy, you must cultivate greener cities" [9][12].

\section{Efforts to Arrange the Urban Morphology with Spatial Planning Instruments}

From the description above, social transformation has not shaped the morphology of Indonesian cities as expected, namely organized urban spatial structures, efficient urban functions, and visually aesthetic city faces. One of the reasons is that it has not yet functioned optimally the Regional Spatial Plan as an instrument to guide city development. We must recognize that conventional urban development implementation practices are based on Law no. 26/2007 on Spatial Planning. It shows several weaknesses whose effects can be seen physically from the city's morphological form [14][33][34].

More broadly, in fact, we can identify 7 (seven) forms of past practice weaknesses in the implementation of spatial planning in Indonesia, as stated as follows: (1) top-down in a centralized government system; (2) exclusive, where the role of the Government is very dominant, tends to ignore the role of other stakeholders; (3) focuses on aspects of economic growth without adequate attention to protecting environmental quality and public safety; (4) limited sectorial integration, so that the planning process (planning) is not related to the design process of buildings and infrastructure at a more detailed level. Moreover, the detailed spatial plan is not equipped with zoning regulations as an instrument of development control; (5) out of sync between the planning and programming process (allocation of development funding), so that various development plans are not effectively carried out according to the plan; (6) limited attention to developing local intelligence as a vital planning asset; and (7) spatial planning and implementation are not sufficiently escorted by effective local leadership in realizing the vision of development.

The practice of spatial planning is powerless in controlling rapid urbanization with all its negative impacts, among others: spreading cities that are not organized in all directions, decreasing environmental quality (pollution, congestion, flooding), and deficits in the provision of urban infrastructure and facilities. If the negative trend is allowed to continue, the future of the sustainable development of cities in Indonesia is a big question.

"Conventional" spatial planning is inadequate; therefore, this approach must further be developed in order to answer increasingly complex urban problems where one factor is closely linked with other factors in a non-linear fashion. The "new" spatial planning approach is expected to carry more powerful conceptions and practices by considering various parameters in a more balanced way towards more livable cities, between meeting basic urban needs as well as other more advanced needs, aligning to modernization in parallel with the preservation of local culture, attention to physical development together with strengthening attention to environmental quality, and the provision of infrastructure through cooperation between the private and public parties.

In fact, the idea of "re-invented planning" is not new if we refer to practices that occur in other cities in the world. Traditional spatial planning has been the object of sharp debate and criticism since the early 1960s in North America and, later, in Europe. The evolution of spatial planning concept goes parallel with increasing awareness of environmental issues because urbanization has reduced the environment's carrying capacity (ecological footprint, which continues to increase). Therefore, it is not surprising that green initiatives, which have surfaced, are in the mainstream of urban development. "Green City" becomes a new conception of sustainable urban development to realize more livable cities.

\section{Spatial Policy in Indonesia to Arrange Urban Morphology through Land Readjustment}

Arranging the city's morphology means changing the way of viewing the city, not merely dealing with physical objects, because the city is an organic unity between the built area, humans and their environment (ecosystem). The green city principle emphasizes that economic and ecological interests are not contested but synergized. In it, there are also elements of green infrastructure and architecture suitable for the tropical climate: energy 
conservation, water conservation, saving materials (emphasis on local materials), minimization and re-utilization of waste, green landscaping, pedestrian pathways, and so on [9][15].

Therefore, the principles of green cities are to be developed, which will positively influence the formation of greener city morphology. For Indonesia, this effort must put in the vision of long-term development. Law No. 26/2007 concerning Spatial Planning can be seen as a good momentum to improve spatial planning practices going forward [14].

Urban land consolidation/readjustment as a public policy in the land sector in utilizing the land as allocated to the spatial plan must comply with general legal principles regarding land tenure and land use, as well as general principles that must be considered in granting land rights as a form of government determination.

Regulation of the Head of the Land Agency Number 4 of 1991 concerning Land Consolidation/readjustment explains that there are two types of approaches in the procurement of urban land consolidation/readjustment in Indonesia, namely, first, the top-down approach, which is an approach that is the implementation of the development plan outlined by the government towards the regions, determined as an object of consolidation/readjustment to finance the implementation of the consolidation/readjustment of funds provided from the APBN/APBD, so that consolidated participants are only subject to land donations for the procurement of infrastructure [33][34].

Second, the bottom-up approach is an approach originating from the proposals of community landowners who have been coordinated and wish to regulate their land through a consolidation/readjustment program. This approach focuses more on public awareness of environmental regulation and harmony. The landowning community then submits a request to the government for consolidation/readjustment on their land. Project implementation costs are borne jointly by the participants of the land consolidation/readjustment. Communities are subject to land donations for infrastructure and project implementation.

The basis for the implementation of land consolidation/readjustment is UUPA Article 14, Regulation of the Minister of Agriculture/Head of National Land Agency Number 9 of 1999 concerning Procedures for Granting and Cancellation of State Land Rights and Management Rights, Law of the Republic of Indonesia Number 26 of 2007 concerning Spatial Planning, Government Regulation Republic of Indonesia Number 16 of 2004 concerning Land Stewardship, and Regulation of the Head of National Land Agency Number 4 of 1991 concerning Land Consolidation/readjustment [14][33].

The purpose of land consolidation/readjustment is to achieve optimal land use through increased efficiency and productivity in land use, to (1) meet the need for an orderly, and healthy residential environment, (2) allow landowners to enjoy direct land consolidation/readjustment benefits, both land price increases and other benefits, due to the creation of an orderly environment, (3) increase the equitable results of settlement development so that it can be enjoyed directly by landowners, (4) avoid conflicts that often arise in the provision of land conventionally, (5) accelerate the pace of development of residential areas, (6) curb land administration and save government funding for the cost of building road infrastructure, public facilities, compensation and operations, (7) increase efficiency and productivity of land use [34].

\section{Conclusions}

Efforts to restructure cities' morphology in Indonesia will be far better if done early on when urbanization has not put heavy pressure; population density is not high. At the same time, spaces for manoeuvre are still available. For this reason, attention to small and medium cities is significant, considering that urbanization as a social and economic phenomenon is a necessity, inevitable, and often destructive to environmental quality. When physical development has formed out of control, cities are quickly becoming "obese". Organic development such as this ultimately complicates the city's arrangement because urbanization is basically irreversible. Even if you can, it will be costly and difficult to do.

However, it is never too late to do something for a better future of our cities, which is more sustainable. As one well-known architect once promoted a new urbanism movement in the mid-1980s, [3][15], "It may be too late for some cities, but it is not too late for Asia". For this reason, intervention through the formal system (planning, zoning regulations, and design) is still needed in guiding so that public and private sector investments can be well-targeted.

Planning cannot stand alone but must be strengthened by operational instruments at a more detailed level, namely zoning regulations and urban design. Thus, arranging the city's morphology can be done as a whole: "as a whole and as a piece".

Through these various efforts, the morphology of cities in Indonesia is expected to fulfill four main elements: (1) structural elements (cities become more efficient with better public services), (2) functional elements (various urban activities run optimally, synergizing with each other to ensure the interests of all groups in a balanced manner, while reducing the forms of negative externalities, including congestion, disaster, slums, and injustice, (3) visual elements (cities supported by better aesthetic values, by developing as much as possible the diverse traditional architecture), and, finally (4) environmental elements (cities that wisely protect their natural environment).

For Indonesia, the question that is worth asking is "What kind of city will our next generation inhabit?" The answer 
really depends on how we manage cities to provide equal opportunities for the next generation to enjoy a good quality of life in livable cities. Like the current generation, we certainly do not want to be considered a selfish generation one time because it ignores the next generation's interests.

Limited land in urban areas has always been the reason for the government's slow movement in meeting the community's needs for housing. The best-selling land for development in major cities in Indonesia, in addition to causing scarcity also makes land prices skyrocket so that people's purchasing power over land decreases. In contrast, the phenomenon of population growth and urbanization continues to occur in big cities like Jakarta and increase the demand for housing. This, of course, demands the availability of massive amounts of land.

If left unchecked, issues related to land limitations will have a protracted impact such as the emergence of slums in illegal areas and the widening of urban sprawl phenomena around urban areas. For this reason, alternative solutions are needed that can increase the effectiveness and efficiency of available land so that it can be utilized as a housing development in urban areas. One alternative that can be implemented is the concept of land readjustment for settlements. The popularity of the concept of land readjustment to overcome housing problems may not yet be heard. This can be caused by the lengthy process and complexity of the bureaucracy in the execution of land readjustment and the tendency to implement the concept in agriculture alone. The government should provide maximum socialization and understanding of land readjustment for the community, which is carried out in an integrated manner with related agencies to run well and be synchronized.

Described above as a thought, it is not easy to make it happen. It takes commitment, hard work of all parties (stakeholders) and prioritizes the spirit of togetherness (not sectoral) to create a national territory space that is safe, comfortable, productive and sustainable and to realize development that promotes social-friendly, cultural-friendly and environmentally friendly. Whatever the orientation of the economic development is, it must still be aimed at achieving social justice. Moreover, in the development of the public interest, it must be less likely to incur social and environmental costs to realize a prosperous and socially just Indonesia.

\section{REFERENCES}

[1] Allain, R., "Morphologie urbaine: Géographie, aménagement et architecture de la ville", Armand Colin, 2004, 254p, 2004.

[2] Anom Wiryasa, "Analisis Kelembagaan dalam Pelaksanaan Penataan Ruang Wilayah Provinsi Bali (Institutional
Analysis in the Implementation of Spatial Planning in Bali Province)", 2014.

[3] Derek \& Japha, "Identity through detail: an architecture and cultural aspiration in Montagu, South Africa", 1850-1915', TDSR, vol. II, pp. 17-33, 2019.

[4] Diana Conyers, "Perencanaan Sosial di Dunia Ketiga, terjemahan dari Susetiawan (Social Planning in the Third World)", Affan Gaffar, Gadjah Mada University Press, Yogyakarta, 1984.

[5] Dwijendra, NKA, "Bali Traditional Housing and Settlements", Journal of Settlement Natah, Vol. 1 No. February 1, pp. 8 - 24, 2003.

[6] Ernawi, I.S. "Mainstreaming the "Green Concept" to the Urban Development, Keynote Speech dalam rangka 2nd International Seminar on Tropical Eco-Settlements under the theme of "Green Infrastructure: A Strategy to Sustain Urban Settlements”, 3 November 2010, Sanur - Bali, 11p, 2010.

[7] Firman, T. "Indonesian cities under the 'Krismon': A great 'urban crisis' in Southeast Asia”. Cities. Vol. 16 (2): 69-82, 1999.

[8] Frysa Wiriantari, Syamsul Alam Paturusi, Ngakan Ketut Acwin Dwijendra, Dewa GedeAgung Diasana Putra, "The Value of Catuspatha As A Public Space For The Balinese Community In The Klungkung City, Bali Indonesia: The Struggle For Activities Between Politics, Economics And Socio-Culture", PalArch's Journal of Archaeology of Egypt/Egyptology, 17(7), 11581 - 11593. Retrieved from https://archives.palarch.nl/index.php/jae/article/view/4541.

[9] Gutmann, A. "Common Ground, Common Good: Preface, in Growing Greener Cities: Urban Sustainability in the Twenty First Century", edited by Birch, E.L \& Wachter, S.M, University of Pennsylvania Press, p ix - xii, 2008.

[10] Hall, P. "Seven Types of Capital Cities, 2nd Chapter in Planning Twentieth Century Capital Cities", edited by David Gordon, Routledge - Taylor \& Francis, London, p8-14, 2006.

[11] I Nyoman Widya Paramadhyaksa, Ngakan Ketut Acwin Dwijendra, Ni Ketut Pande Dewi Jayanti, I Kadek Merta Wijaya, "Orientation on Spatial Planning in Pinggan Village, Kintamani District, Bangli Regency, Bali, Indonesia”, Solid State Technology Volume: 63 Issue: 6, 2020.

[12] Juergensmeyer, J.C. \& Roberts, T.E. "Land-use Planning and Development Regulation Law", Hornbook Series, Thomson-West, USA, 2003.

[13] Kardash, H. "The Transformation of Public Housing Provision in Egypt and the Role of Self-Help", Unpublished PhD Thesis, University of Newcastle upon Tyne: Newcastle, 1993.

[14] Law No. 26/2007 concerning "Spatial Planning (Undang-Undang No. 26/2007 tentang Penataan Ruang)"

[15] Leks, Eddy Marek, "Analisis dan Evaluasi peraturan Perundang-Undangan Tentang Perumahan Rakyat (Analysis and Evaluation of Legislations on Public Housing)", Badan Pembinaan Hukum Nasional Kementerian Hukum dan Hak Asasi Manusia RI, Jakarta, 2015.

[16] Ngakan Ketut Acwin Dwijendra. I Putu Gede Suyoga, "Analyze of Symbolic Violence Practices in Balinese 
Vernacular Architecture, Bali Indonesia”, International Journal of Innovation, Creativity and Change, Vol. 13, Issue 5, 18 June 2020. Retrieved from https://www.ijicc.net/imag es/vol_13/Iss_5/13543_Dwijendra_2020_E_R.pdf, 2020.

[17] M. V. Yogantari, N. K. A. Dwijendra, "Visual Exploration Using Acrylic Paint on Used Fashion Items for Sustainable Use", In: International Journal of Psychosocial Rehabilitation, Vol. 24, No. 03, DOI: 10.37200/IJPR/V24I3 /PR201902, 2020.

[18] Ngakan Ketut Acwin Dwijendra, "From Tradition to Modernization in Morphological Process of Indigenous Settlement Patterns in Bali, Indonesia", International Journal of Advanced Science and Technology, 29(8s), 172 - 184. Retrieved fromhttp://sersc.org/journals/index.php/IJAST/ar ticle/view/1043, 2020.

[19] N. P. S. Nurjani, N. K. A. Dwijendra, "How Traditional Balinese Houses Can Adjust and Cater for International Tourist in the Canggu Area, Bali Indonesia? In: International Journal of Psychosocial Rehabilitation, Vol. 24, No. 03, DOI: 10.37200/IJPR/V24I3/PR201901, 2020.

[20] Ngakan Ketut Acwin Dwijendra, "Meru as a Hindu Sacred Building Architecture with a High Roof and Resistant to Earthquakes in Bali, Indonesia," Civil Engineering and Architecture, Vol. 8, No. 3, pp. 350 - 358, 2020. DOI: 10.13189/cea.2020.080319.

[21] N. K. A. Dwijendra, "Identity Struggle Perspective in Car-Shaped Shrine in Paluang Temple, Nusa Penida Bali, Indonesia", International Journal of Psychosocial Rehabilitation, Vol. 24, No. 4, DOI: 10.37200/IJPR/V24I4/ PR201653, 2020.

[22] Wa Ode Sifatu, Herman Sjahruddin, Yana Fajriah, Ngakan Ketut Acwin Dwijendra, Adi Santoso, "Innovative Work Behaviors in Pharmacies of Indonesia: Role of Employee Voice, Generational Diversity Management and Employee Engagement", SRP; 11(2): 725-734. DOI: 10.31838/srp.2020.2.105. Retrieved from http://sysrevphar m.org/?mno=118846, 2020.

[23] Ngakan Ketut Acwin Dwijendra, Frysa Wiriantari, Desak Made Sukma Widiyani, Anak Agung Ayu Sri Ratih Yulianasari, Arya Bagus Mahadwijati Wijaatmaja, "Transformation of Catuspatha in Bali Indonesia: Alteration Ideas from Empty Space to Aesthetic Element of City", Rupkatha Journal on Interdisciplinary Studies in Humanities. Volume 12, Number 6, 2020. DOI: 10.21659/rupkatha.v12n $6.15,2020$

[24] Made Agus Mahendra, Syamsul Alam Paturusi, Ngakan Ketut Acwin Dwijendra, DewaGede Agung Diasana Putra, "The Meaning Of Local Culture Elements And Urban Elements As Forming The Identity Of The Klungkung Urban Area, Bali, Indonesia", PalArch's Journal of Archaeology of Egypt/Egyptology, 17(7), 11563 - 11580. Retrieved from https://archives.palarch.nl/index.php/jae/arti cle/view/4539, 2020.

[25] Malverti, X. \& Picard, A, "La fabrication des villes, GEVR", Ecole d'Architecture de Grenoble \& Ecole d'Architecture de Normandie, 269p, 2020.

[26] Ngakan Ketut Acwin Dwijendra, Akhmad Anwar Dani, Dian Wardiana Sjuchro, Elena N. Klochko, Yenni Patriani, "Political And Social Infrastructure Towards High Quality Tourism Sites", European Journal of Molecular \& Clinical
Medicine, 2020, Volume 7, Issue 11, Pages 1764-1773, 2020.

[27] Ngakan Ketut Acwin Dwijendra, Frysa Wiriantari, Desak Made Sukma Widiyani, Anak Agung Ayu Sri Ratih Yulianasari, Arya Bagus Mahadwijati Wijaatmaja, "Transformation of Catuspatha (Crossroad) In Bali Indonesia: Alteration Ideas From Empty Space To Aesthetic Element Of City, Solid State Technology Volume: 63 Issue: 6, 2020 .

[28] Ngakan Ketut Acwin Dwijendra, "Cultural Value Transformation in Traditional Market Spatial Planning in City of Denpasar, Gianyar and Klungkung - Bali, Indonesia", Journal of Sustainable Development; Vol. 10, No. 4; 2017 ISSN 1913-9063 E-ISSN 1913-9071. Published by Canadian Center of Science and Education, 2017.

[29] Ngakan Made Anom Wiryasa and Ngakan Ketut Acwin Dwijendra, "Institutional Structure Models in Implementation of Spatial Planning", Journal of Sustainable Development; Vol. 10, No. 4; 2017 ISSN 1913- 9063 E-ISSN 1913-9071. Published by Canadian Center of Science and Education, 2017.

[30] Ni Luh Putu Dessy Dharmayanty, Syamsul Alam Paturusi, Ngakan Ketut Acwin Dwijendra, Ni Ketut Agusinta Dewi, "The Meaning of Vertical Housing for Balinese People, the Debate between Cultural Demands and the Need for Urban Housing in Bali, Indonesia", In: International Journal of Psychosocial Rehabilitation, Vol. 24, No. 7, DOI: 10.37200/IJPR/V24I3/PR201902, Retrieved from https://www.psychosocial.com/article/PR280300/20770, 2020 .

[31] Peterson, J.A, "The Impact of Sanitary Reform upon American Urban Planning, 1840 - 1890, in Introduction to Planning History in the United States, edited by Krueckeberg", D.A, the Center for Urban Policy Research, Rutgers University, New Jersey, p13 - 39, 1983.

[32] Regulation of the Head of the Land Agency Number 4 of 1991 concerning "Land Consolidation (Peraturan Kepala Badan Pertanahan Nomor 4 Tahun 1991 tentang Konsolidasi Tanah)", 1991.

[33] Regulation of the Minister of Agriculture/Head of National Land Agency Number 9 of 1999 concerning "Procedures for Granting and Cancellation of State Land Rights and Management Rights", 1999.

[34] Setiawan, Yudhi, "Instrumen Hukum Campuran (Gemeenschapelijkrecht) dalam Konsolidasi Tanah", Rajawali Pers, Jakarta, 2019.

[35] Shiferaw, D, "Self-initiated Trans-formations of Public-Provided Dwelling in Addis Ababa, Ethiopia". Cities. Vol. 15 (6): 437-448, 1998.

[36] Sinai, I. "Moving or Improving: Housing Adjustment Choice in Kumasi, Ghana", Housing Studies, Vol. 16 (1): 97-114, 2001

[37] Sitorus, Oloan, "Konsolidasi Tanah, Tata Ruang, dan Ketahanan Nasional (Land Consolidation, Spatial Planning, and National Resilience)", STPN Press, Yogyakarta, 2020.

[38] Soetomo, S, "Dari Urbanisasi ke Morfologi Kota, Mencari Konsep Pembangunan Tata Ruang Kota yang Beragam (From Urbanization to City Morphology, Seeking Diverse 
Urban Spatial Development Concepts)", Cetakan I, Badan Penerbit Universitas Dipenogoro, Semarang, 123p, 2020.

[39] Statistical Bureau of Bali (Badan Pusat Statistik Bali), "Bali dalam Angka (Bali in Numbers)", Denpasar; BPS Bali, 2018.

[40] Sumardjono, Maria S.W, "Tanah dalam Perspektif Hak Ekonomi, Sosial dan Budaya (Land in the Perspective of Economic, Social and Cultural Rights)", Kompas, Jakarta, 2008.

[41] Nuryanto, Ngakan Ketut Acwin Dwijendra, Syamsul Alam Paturusi, I Made Adhika, "Technic and Mystics of Tukang Wangunan in Sundanese Traditional Houses in Indonesia (Case Study: Baduy Tribe Community-Banten)," Civil Engineering and Architecture, Vol. 9, No. 2, pp. 533 - 544, 2021. DOI: 10.13189/cea.2021.090226.

[42] Birkhamshaw, Alex J and J.W.R. Whitehand, "Conzenian Urban Morphology and the Character Area of Planners And Residents", Urban Design International (17), 4-17, 2012.

[43] Budiharjo, Eko, "Arsitektur dan Kota di Indonesia (Architecture and Cities in Indonesia)", Bandung: Alumni, 1984.

[44] Danisworo, Muhammad, "Urban Landscape Sebagai Komponen Penentu Kualitas Linkungan Kota (Urban Landscape as a Determining Component of the Quality of the City Environment)", Makalah Jurusan Arsitektur Fakultas Teknik UK. Petra. Surabaya, 1989.

[45] Lynch, Kevin, "The Image of The City", Cambridge, Massachusetts: MIT Press, 1969.
[46] Mumford, Lewis, "The Myth of The Machine" (Vol. I): Technics and Human Development: New York City: Brace and Jovanovich, 1997.

[47] Nielsen, G., J. Nelson, C. Mulley, G. Tegner, G. Lind and T. Lange, "Public Transport - Planning the Networks - HiTrans Best Practice Guide 2", Stavanger, Norway: European Union Interreg III and HiTrans, 2005.

[48] Philip James and Daniel Bound, "Urban Morphology Types and Open Space Distribution in Urban Core Areas", Urban Ecosystem 12:417:424 doi 10.1007/s11252-009-0083-1, 2009.

[49] Smailes, R.J. "Some Reflection on the Geographical Description and Analysis of Townscape", In the Institute of British Geographer Transaction and Paper, 2005.

[50] Siluh Putu Natha Primadewi, Ngakan Putu Sueca, Ngakan Ketut Acwin Dwijendra, Ni Ketut Ayu Siwalatri, "Emerging Architect's Design Method in Designing Tourist Accommodation Case Study: Tourist Accommodation in Ubud, Bali," Civil Engineering and Architecture, Vol. 9, No. 2, pp. 271 - 280, 2021. DOI: 10.13189/cea.2021.090201.

[51] I Nyoman Widya Paramadhyaksa, Ngakan Ketut Acwin Dwijendra, "The Complexity of Orientation in Traditional Village Architecture in Bali, Indonesia", Humanities Diliman, A Philippine Journal of Humanities, HD Vol. 18 No. 1, January-June 2021.

[52] Wiryasa, Ngakan Made Anom, and Ngakan Ketut Acwin Dwijendra, "Institutional Structure Models in Implementation of Spatial Planning." Journal of Sustainable Development. https://doi.org/10.5539/jsd.v10n 4p56, 2017. 